\title{
Unpublished Block Statue Inv. No. 326 at Mallawi Museum
}

\section{By}

\section{Dr. Saber Mohamed Sadek Salem ${ }^{1}$}

Lecturer at the department of Archaeology Faculty of Arts, Damanhour University.

\begin{abstract}
:
This article deals with an unpublished block statue located currently in Mallawi Museum. This statue has technical and linguistic features which suggest its belonging to in the Saite period. the present article shows both of these technical and textual features that reflect different aspects of the statue such as the aim of the statue carving, its original place and some significances concerning its original place and its representations.
\end{abstract}

\section{Keywords:}

Block statue, Mallawi Museum, El-Bahnasa Magazine, Dw3-m-Mn-nfr (?)-Late Period, Dhwty, Hwt-ḥr

The owner of the statue: $D w 3-m-M n-n f r(?)$

Titles: $h 3 t y-{ }^{\prime} m$ wnwt "the count of the Hare-nome" and $h 3 t y-{ }^{\circ} n$ Hmmw "the count of Hmnw".

Material: granite.

\section{Dimensions:}

Total height about: $43.5 \mathrm{~cm}$.

Total width about: $30 \mathrm{~cm}$.

The head height: $10 \mathrm{~cm}$.

The base: 8 x 21 c.m.

The back pillar: $23 \times 8.5 \mathrm{~cm}$.

Provenance: Unknown.

\footnotetext{
${ }^{1}$ Lecturer at the department of Archaeology, Faculty of Arts, Damanhour University. Email: saber.salim@art.dmu.edu.eg
} 
Current Location: This Statue is registered under number 471 in AlMinya Antiquities register at El-Bahnasa Magazine, and currently, it has been transferred to Mallawi Museum, it has the inventory number 326.

Dating: Although the double wide wig, which the statue wears, was very frequent during the end of the $25^{\text {th }}$ dynasty, ${ }^{2}$ the carving type of this statue belongs to the Saite period, ${ }^{3}$ Therefore, the author suggests Dating of this statue at the beginning of the reign of Psamtik I, 650 B.C. ${ }^{4}$

Bibliography: Unpublished

\section{Description:}

This statue belongs to the type known as block statues, ${ }^{5}$ which represents the owner of the statue in a squatting position wearing a cloak covering most of the body except for the hands, head and sometimes feet. The details of the body are visible from under the cloak. Usually, the cloak engraved with hieroglyphic texts or with a view of the deceased is located in front of a deity. ${ }^{6}$ this type of statues named in the ancient Egyptian language his and $h s t .{ }^{7}$ Berlin dictionary also translated the term snn as meaning "kneeling and squatting statues".

It have been known in Egyptian art since the time of the Middle Kingdom and it became the most common method of sculpture for

\footnotetext{
${ }^{2}$ Bosse, K., Die menschliche Figur in der Rundplastik der ägyptischen Spätzeit von der XXII. Bis zur XXX. Dynastie, in: $\ddot{A} F$ 1, 1936, Taf. XVI; Bothmer states that the first appearance of the double wide wig was at the beginning of the Twenty-sixth Dynasty. See: Bothmer, B., The Egyptian Sculpture of Late period, New York, 1960, p.25.

${ }^{3}$ For more details on the statues of the Twenty-fifth and Twenty-sixth Dynasties, see: Josephson, J.A.\& Eldamaty, M.M., Statues of the XXVth and XXVIth Dynasties: Catalogue general of Egyptian antiquities in the Cairo Museum: Nos. 48601-48649, The Supreme Council of Antiquities Press, Cairo, 1999.

${ }^{4}$ For more models of block statues dating back to the same period to which the statue is attributed, see: (Cairo, Egyptian Museum CG 42196, 42217, 42249, 42250, 42270, 48605, 48616, 48617, 48619, 48622, 48623, 48624, 48626, 48627, 48629, 48632, 48633, 48635, 48637, 48640, 48642, 48644, 48648); (Alexandria, Bibliotheca Alexandrina BAAM 598); (New York, Metropolitan Museum 1982.318); (Los Angeles, Los Angeles County Museum of Art 48.24.8); see also (London, British Museum EA 1007, 48039).

${ }^{5}$ This type of statues is also known as the cube statue. See: Lurker, M., The Gods and Symbols of Ancient Egypt: an Illustrated Dictionary, London, 1980, p.48.

${ }^{6}$ Radawan. A., "Gedanken zum Würfelhocker", in: GM 8, 1973, p.2 $\vee-3$ l.

${ }^{7}$ El-Damaty, M., Squatting Statues in the Cairo Museum, MDAIK 46, 1990, p.2.

${ }^{8} \mathrm{~Wb}$,III, 460 (6).
} 
individuals until the Late Period. ${ }^{9}$ They are sculpted from a cubic block, from which only the head emerges. The thighs are brought up to the chest

and the arms are usually crossed on the knees. They were less expensive and more durable than other types of statuary.

The statue under study is carved from granite, it is found in two pieces, the head and the rest of the statue, and the statue is now complete after the restoration of the head. Currently, it is on display in the Mallawi Museum Inv. No. 326 (figs.1, 2, 3, 4, 5, 6, 7, 8, 9).

It seems that the owner of the statue was represented naked, as there are no traces of a belt on the back, or a dress covering his buttocks nor any traces of a kilt on the front. In addition, the lines shown on the joints of the feet are not fringes of the kilt. This nudity is a unique type by itself.

The owner of the statue puts his arms crossed over his knees, while the hands are carved in a high relief., Holds a lettuce plant ${ }^{10}$ in his right hand, and simplifies the left hand on the surface of the cube statue.(fig.3) The back of the statue is covered with a rectangle inscribed block, (fig. 2) and the elegant waist and the muscles are shown below the shoulders.

The head of the owner of the statue rises from the cubic structure to slightly upward, he wears a double wide wig free of slits, ${ }^{11}$ starting from the middle of the forehead and dropping from the front to the shoulders, revealing the ears and reaching from the back to the beginning of the back pillar. The face is ideal, adorned with a short beard attached to the chin, completely intertwined with the upper surface of the statue. The

\footnotetext{
${ }^{9}$ The block statues appeared in different styles. For more about the basic shapes and different types of these statues, see: Schulz, R., Block Statue, in: UCLA Encyclopedia of Egyptology, ed. Wendrich. W, Los Angeles, 2011, pp.1-4, figs.2,3.

${ }^{10}$ The hands of these statues are normally empty; in a few models, the extended right hand holds any of these symbols, such as the menat or sistrum, as well as ankh $\left({ }^{(} n h\right)$, maat $\left(m 3^{\complement} t\right)$, djed $(\underline{d} d)$, and tit $(t j t)$ signs. However, lettuce, as a symbol of renewal and fertility, became the most important of these attributes. See: Schulz, R., Op.cit, p.3.

${ }^{11}$ The widespread use of bouffant flat wigs dates back to the beginning of the twentysixth dynasty. See: Levin, K., The Male Figure in Egyptian and Greek Sculpture of the Seventh and Sixth Centuries B. C., in: AJA 68, 1964, p.25; This wig has become a replacement for the grooved wig that disappeared during the reign of King Nekau II. See: Bosse, K., Op.cit, Taf. XV.
} 
mouth is straight and sharp, while the nose is thin and aquiline. The eyes are wide with curved eye brows. (figs.1,3)

There is a height relief between his feet, its width is $6 \mathrm{~cm}$, represent the upper part of Hwt-hr Goddess in the human shape, inscribed inside a rectangle frame. A representation of a kneeling man can be noticed under this frame. This pose usually represents a God inside a Naos. (figs. 1

The artist exploited only the front part of the statue and the block of its back to inscribe the texts. The text on the front consists of two vertical lines of hieroglyphics in $4 \mathrm{~cm}$ in width respectively, while the referred rectangle frame is inscribed between them, and the texts of the back pillar have two vertical lines of hieroglyphics, while the base of the statue has no inscriptions. (figs.1, 2, 6,7)

The inscriptions:

Text on the front

(1)

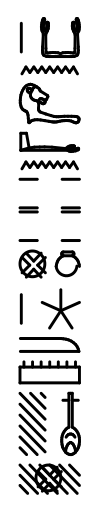

\section{Text on the back pillar}

(1)

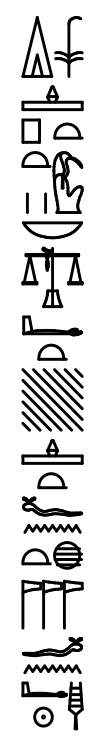

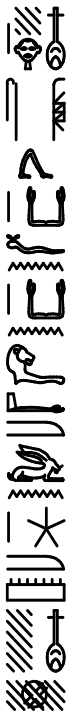

\section{Transliteration and translation:}

\section{-Text on the front:}

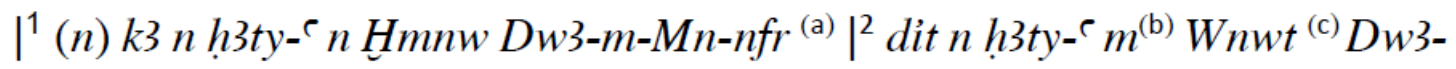
$m-M n-n f r$

$\left.\right|^{1}$ For the soul of the count of Hmnw (who is called) Dw3-m-Mn-nfr $\left.\right|^{2}$ Offering to the count of the Hare-nome (who is called) Dw3-m-Mn-nfr 


\section{-Text on the Back Pillar:}

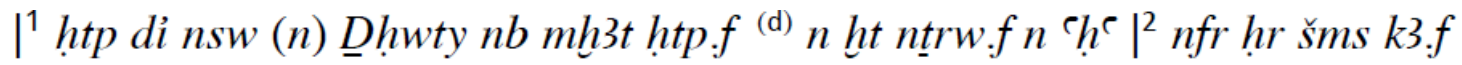
(d) * $n k 3 n h 3 t y-{ }^{\circ} m$ Wnwt Dw3-m-Mn-nfr

$\left.\right|^{1}$ May the king give an offering (to) the god Dhwty, Lord of Balance. May he grant from the things belong to his Gods steadily $\left.\right|^{2}$ May he has a happy face. May he follows his soul. For the spirit of the count of the Hare-nome (who is called) $D w 3-m-M n-n f r$.

\section{Textual Notes:}

(a) The last two signs in the name of the statue are obscured, so its reading isn't confirmed. Particularly, they are not mentioned through the names which Ranke collected, including a recorded name close to the current name: $d w 3-m-n f r$, which dated back to the New Kingdom. ${ }^{12}$

(b) The title of the statue $h 3 t y-{ }^{-} m W n w t$ is mentioned through the titles recorded by Ward without the letter $\mathrm{m}^{13}$, and so without the genitival $\mathrm{n}$, although the genitival $\mathrm{n}$ was used in some titles outside our text, with $h 3 t y-{ }^{-}$and the region name, such as $h 3 t y-{ }^{-} n 3 b \underline{d} w^{14}$ and $h 3 t y-{ }^{C} n$ Iwnw. ${ }^{15}$

(c) The nome Wnwt is written briefly: instead of its complete form, which is written in various ways outside our text, such as:

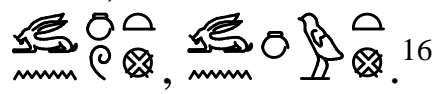

(d) There are some reversed signs, i.e. its direction doesn't suit the text general direction such as the sign. $\mathrm{f}$ (the horned serpent); it has a reversed direction in two places on the back pillar text, the first in column no. (1) after the word $h t p$, and the second in column no. (2) after the word $k 3$.

\footnotetext{
${ }^{*}$ There is an example for these sentences in another statue of $h^{c} m w 3 s t$ at Walters Art Museum, acc.no.22.68, from New Kingdom, $18^{\text {th }}$ Daynasty, reign of Amenhotep III. See: Schulz, R., Small but Beautiful- the block statue of KHAEMWASET, in: Servant of Mut: Studies in Honor of Richard A. Fazzini, Brill, 2008, p.217.

${ }^{12}$ Ranke, PN I, 398 (13).

${ }^{13}$ Ward, Titles, p. 105 (870).

${ }^{14}$ Ward, Titles, p. $105(865)$

${ }^{15}$ Ward, Titles, p. 105 (866).

${ }^{16}$ Gauthier, $D G$, I, 196-197. See also: Drew-Bear, M., Le nome hermopolite: Toponymes et sites, in: ASP 21, Missoula,1979.
} 


\section{General Commentary}

\section{The aim of the statue carving:}

The type of block statue in itself reflects the desire of the dead to return to life after death, as the squatting pose, in which the owner of the statue appears, resembles the pose of the embryo, while the mother's womb is represented by the block of the stone, which encircles the statue as an embryo. This means that the owner of the statue will return to life through a new birth-process. ${ }^{1}$ The pose, which the block-statue shows, may refer to reverence, submission and humility before the Gods. Furthermore, it represents the relaxation pose for the ancient Egyptian. ${ }^{2}$

\section{The place where the statue is put and its significance:}

protect the statue. ${ }^{3}$ There are some others believe that the idea also involves some protection on the part of the statue for the God himself. ${ }^{4}$

Position of the texts: It was the habit of ancient Egyptians to put the texts on the base or the back pillar. But beginning from the $18^{\text {th }}$ dynasty the Egyptian artist started to use the body of the statue to inscribe his texts, and to represent some Gods in order to draw the attention to the statue. $^{5}$

The text on this statue asserts that it had been put in one of the divine temples belonging to Dhwty God, as the first line on the back pillar refers to this God as a collector and a distributer of the Gods' offerings. Hence, we read:

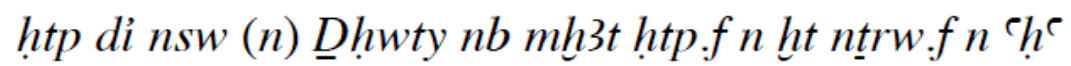

"May the king give an offering" (to) the God Dhwty, Lord of Balance. May he grant from the things belonging to his Gods steadily. "

\footnotetext{
${ }^{1}$ Westendorf, W., Da Alte Ägypten, Baden, 1968, p.80.

${ }^{2}$ Radawan. A., Op.cit, p.28,30. For more on the different opinions on the purpose of block statues, see also: Wilkinson, R., Symbol and Magic Egyptian Art, Thames and Hudson, 1997, p.34., Schulz, R., Block Statue, p.6.

${ }^{3}$ Otto, E., Zur Bedeutung der ägyptischen Tempelstatue seit dem Neuen Reich, Orientalia 17, 1948, pp.458-459; Bonnet, H., Herkunft und Bedeutung der naophoren Statue, MDAIK 17, 1961, p.91-98.

${ }^{4}$ Ranke, H., Eine spätsaitische Statue in Philadelphia, MDAIK 12, 1943, p.107.

${ }^{5}$ Russmann, E., Egyptian Sculpture, London, 1990, p.157.

${ }^{6}$ For more on the offering formula Htp di nsw. See: Smither, P.C.," The Writing of htp-d'i-nsw in the Middle and New Kingdoms " JEA 25, No .1, 1939, pp.34-37; Also there is a comprehensive study excuted by Barta for this formula: Barta,W, Aufbau
} 
Here the text explicitly refers to Dhwty as a God responsible of granting the Gods' offerings to the dead, so the statue might have been put in one of these Gods temples in Wnwt nome. Putting the statue in Dhwty's temple had an obvious goal as indicated by the previous text: namely, receiving some of the offerings which Dhwty God distributes, as previously referred to. This process named wDb, since the Old Kingdom, and whom was responsiple for the mentioned $w \underline{d} b$ entitled $h r y \quad w \underline{d} b$ as Gardiner asserted. ${ }^{1}$

Perhaps, scholars believe that just the presence of this statue in the temple and his participation in the offerings distributed by Dhwty God would turn him into an imperishable being as the $b 3$, as well as commemorating the dead person. However, some of them believe that

one of the goals of putting these statues in the temples is that the Gods would give those people lives through their statues. ${ }^{2}$

\section{The purpose of putting $H w t-h r$ representation between the legs of the statue:}

The representation between the legs of the statue is for Hwt-hrr Goddess. However, scholars believe that all the statues that represented Naos of the Gods aimed to glorify the statue through merging him with the God he chose. In addition, the presence of the representation of Hwt-hr here may have the same aim as the other statues do: that is, to

und Bedeutung der altägyptischen Opferformel ,in: $\ddot{A} F 24$, Glückstadt, 1968, pp.261270.

${ }^{1}$ Gardiner, A., H., Egyptian Grammar, $3^{\text {rd }}$ edit., Oxford, 1973, p.172; Gardiner, A., H., "The Mansion of Life and The Master of kings Largess", JEA 24, London, 1938, p.88.

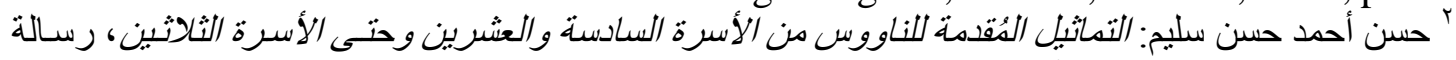

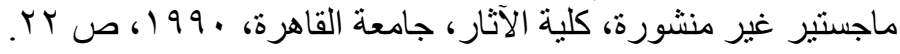




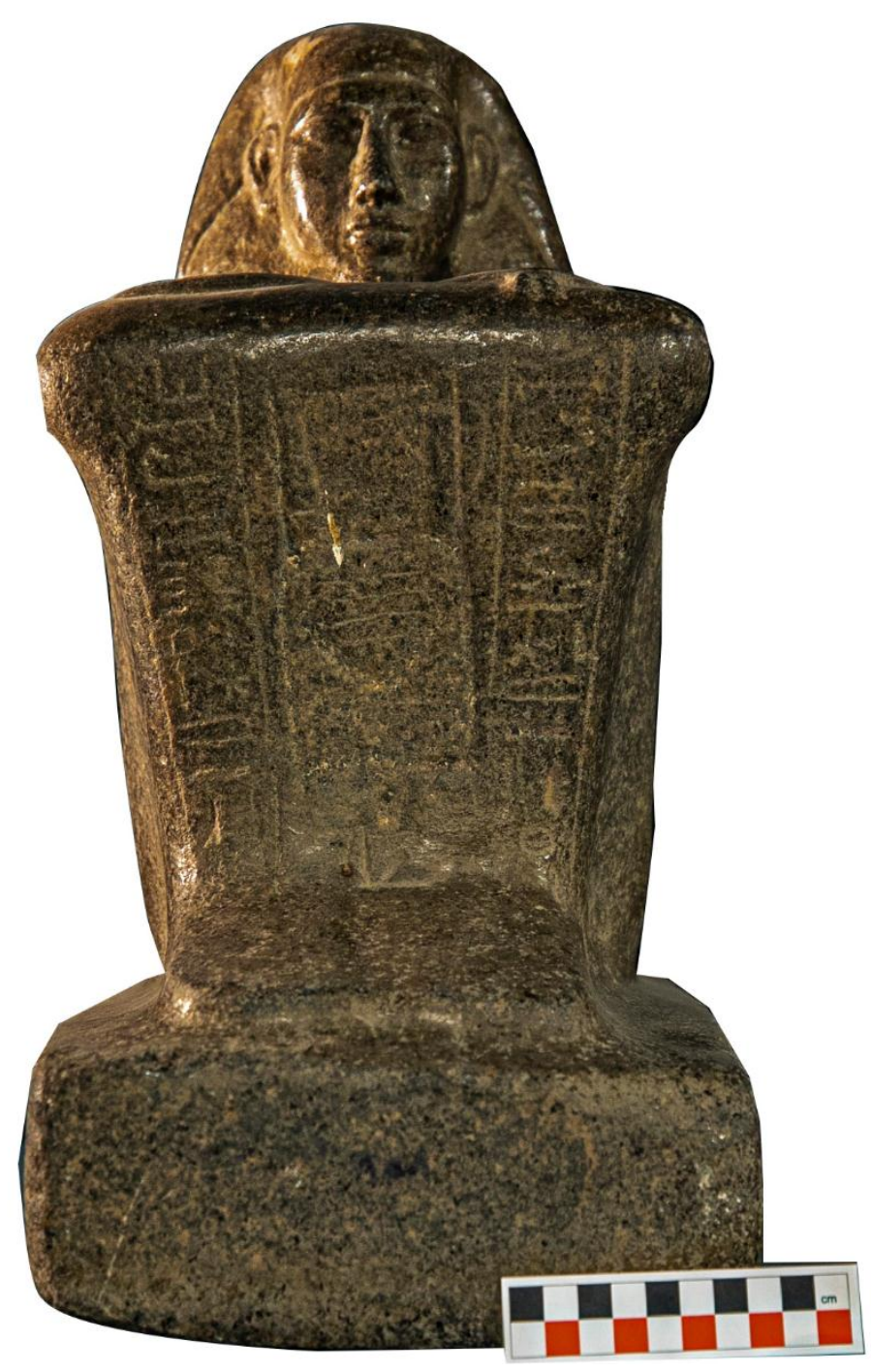

Figure (1)

The front of block Statue Mallawi Museum Inv. No. 326

CMallawi Museum 


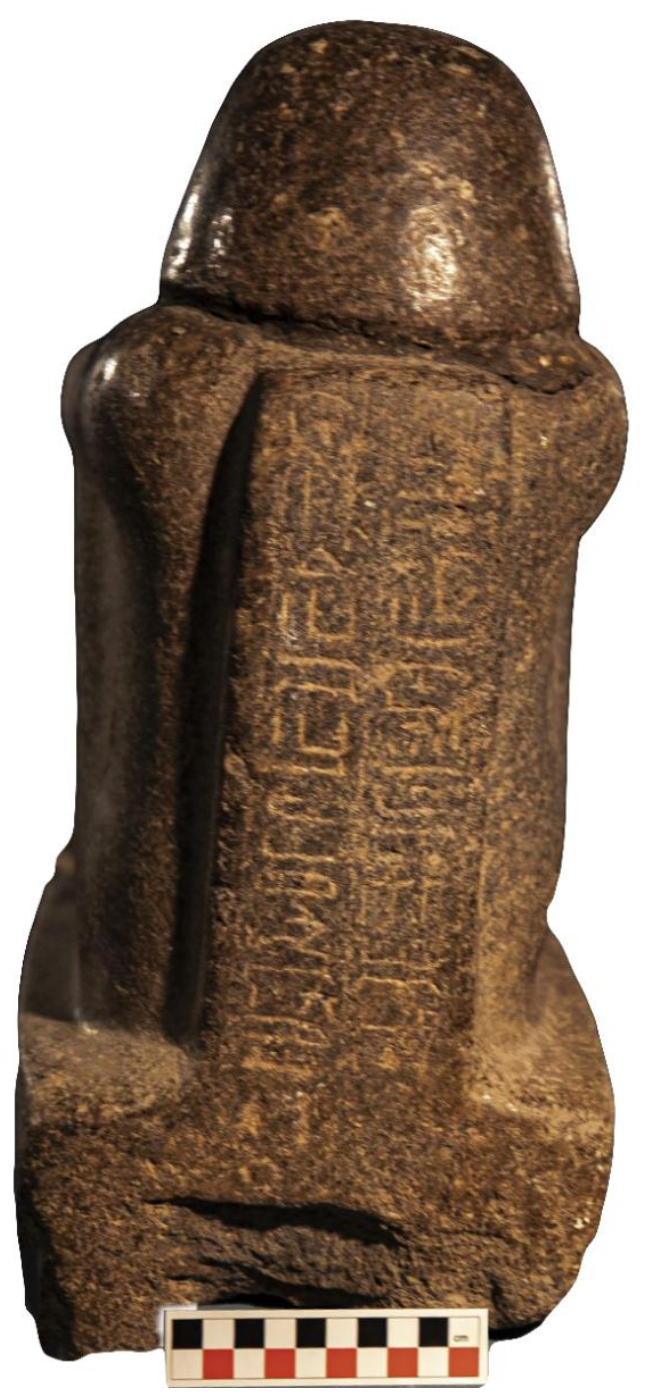

Figure (2)

The back of block Statue Mallawi Museum Inv. No. 326

CMallawi Museum 


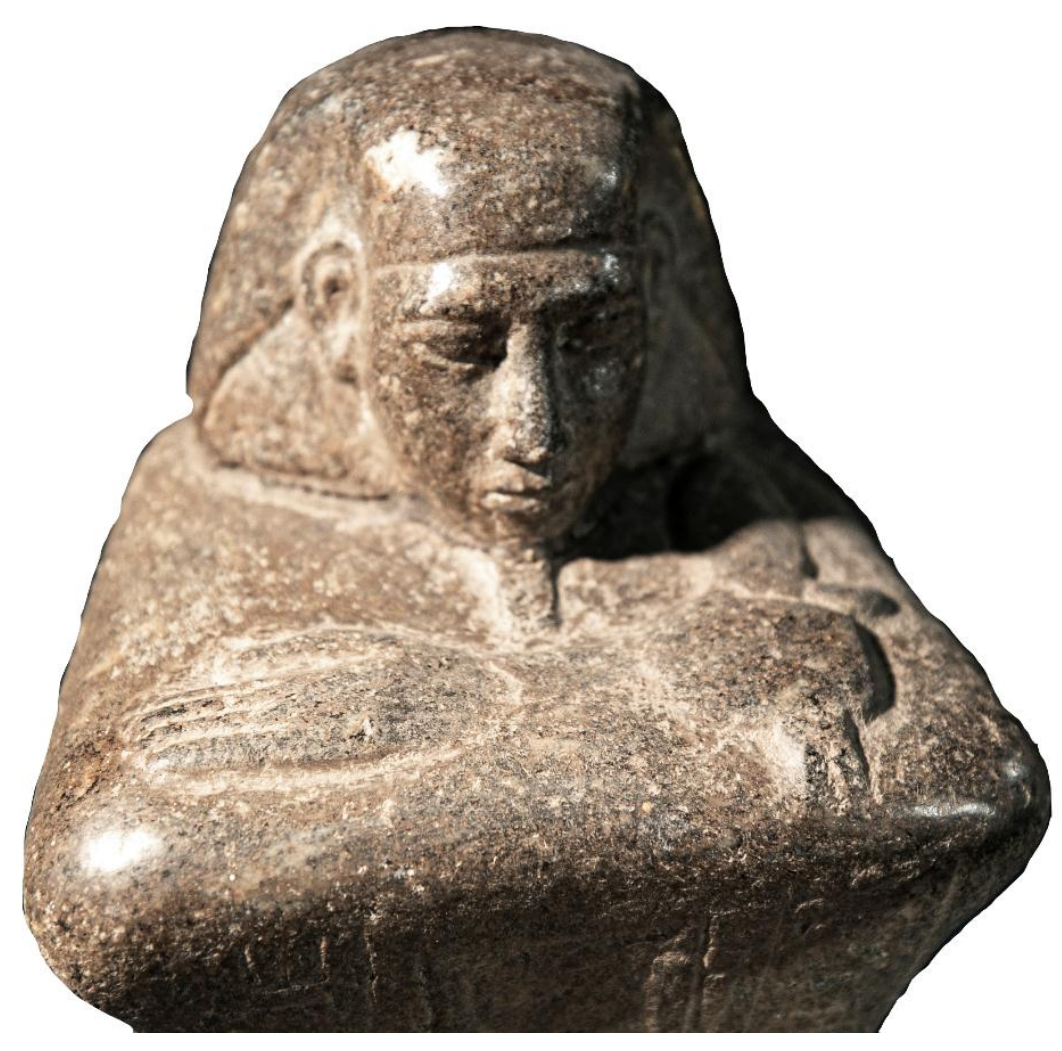

Figure (3)

Upper part of the statue (face and hands)

CMallawi Museum 


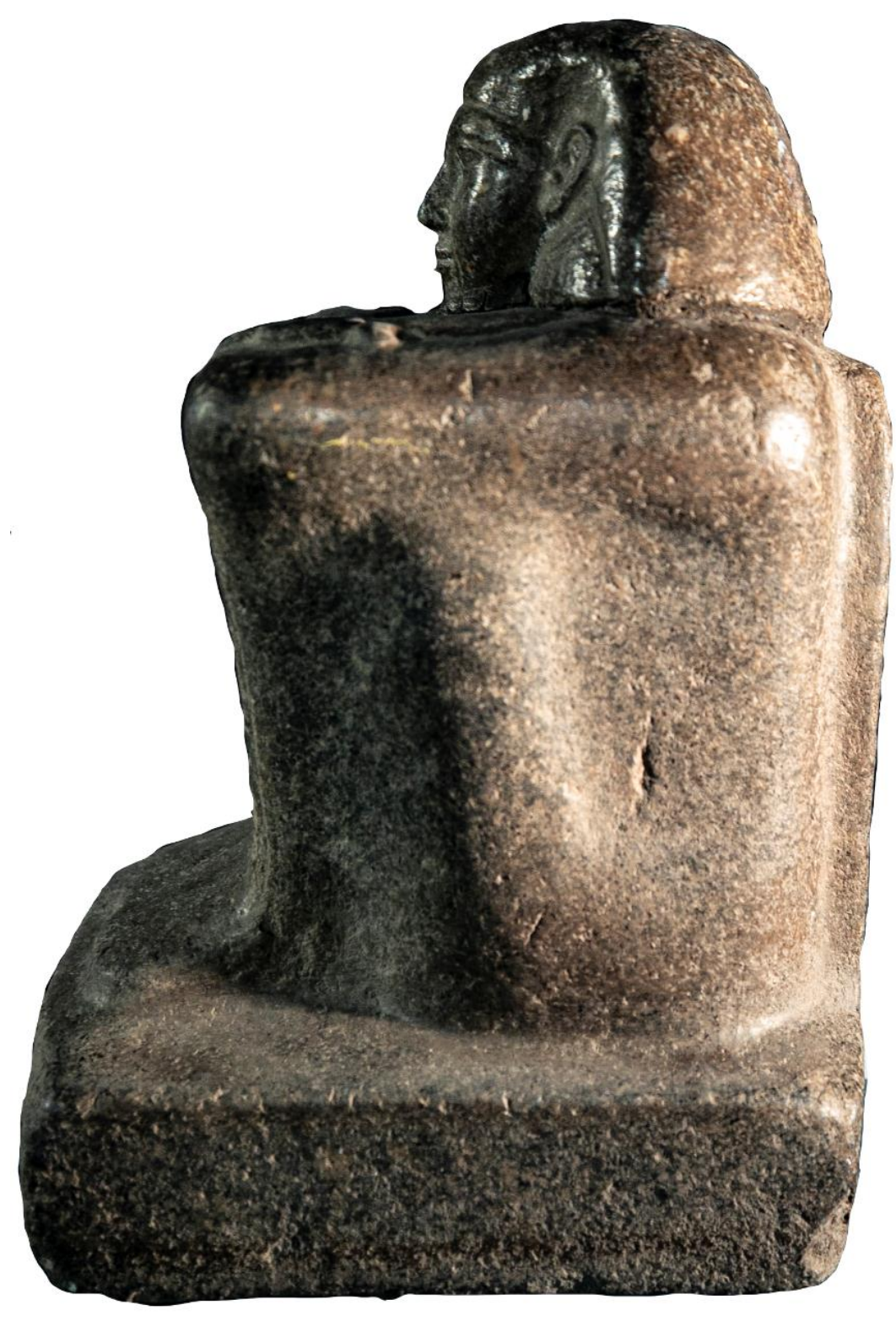

Figure (4)

Side view of the right side of the statue

CMallawi Museum 


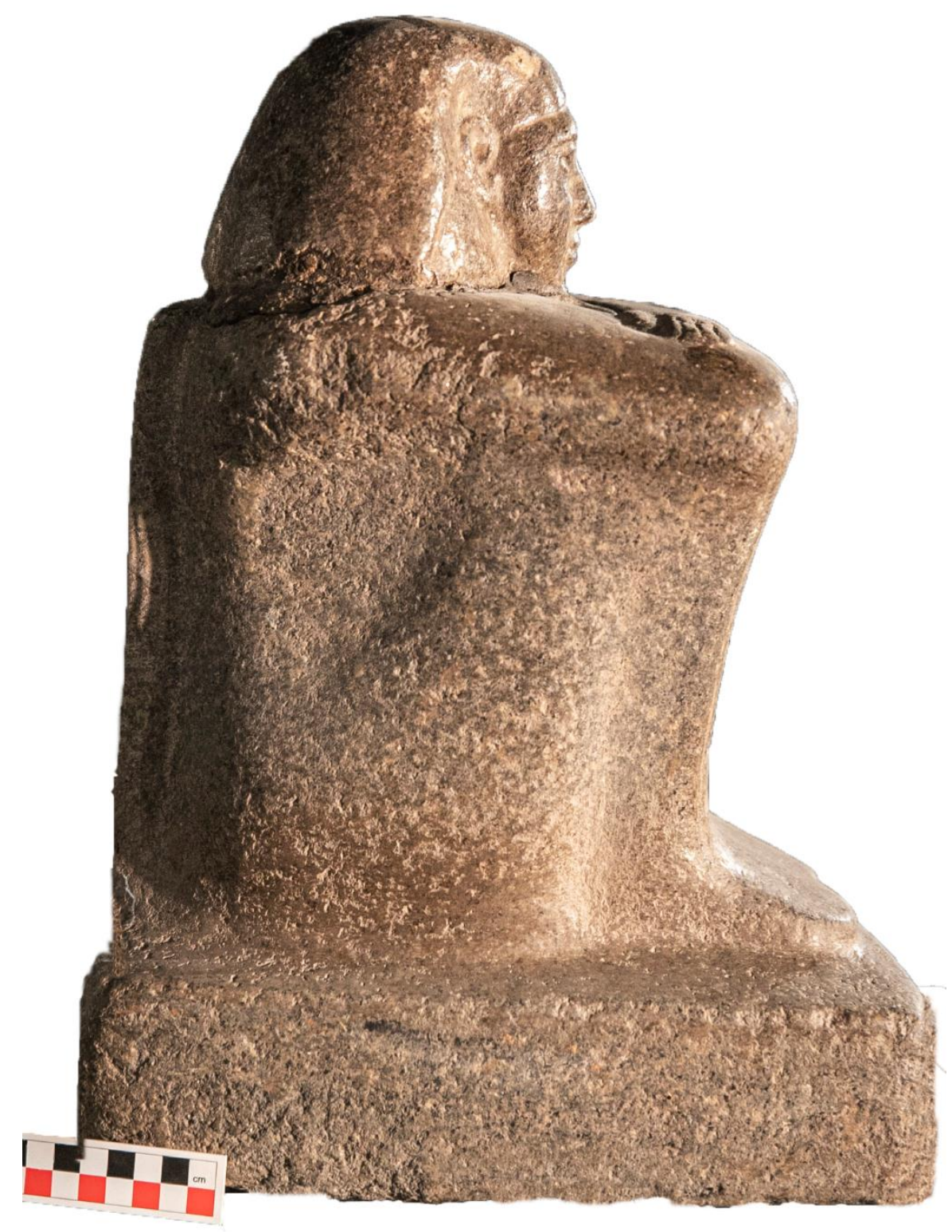

Figure (5)

Side view of the left side of the statue

CMallawi Museum 


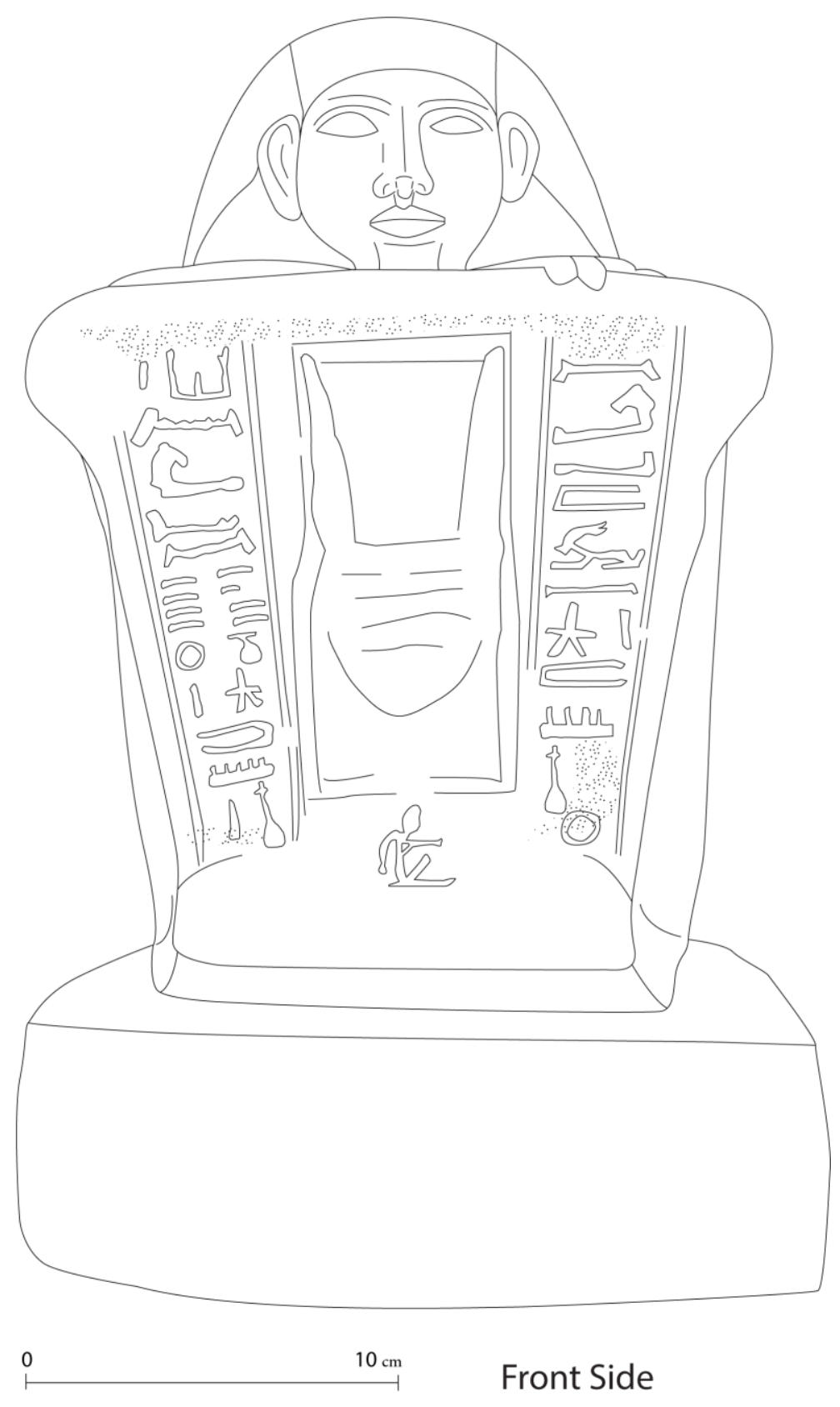

Figure (6)

Facsimile of the front of block Statue Mallawi Museum Inv. No. 326 


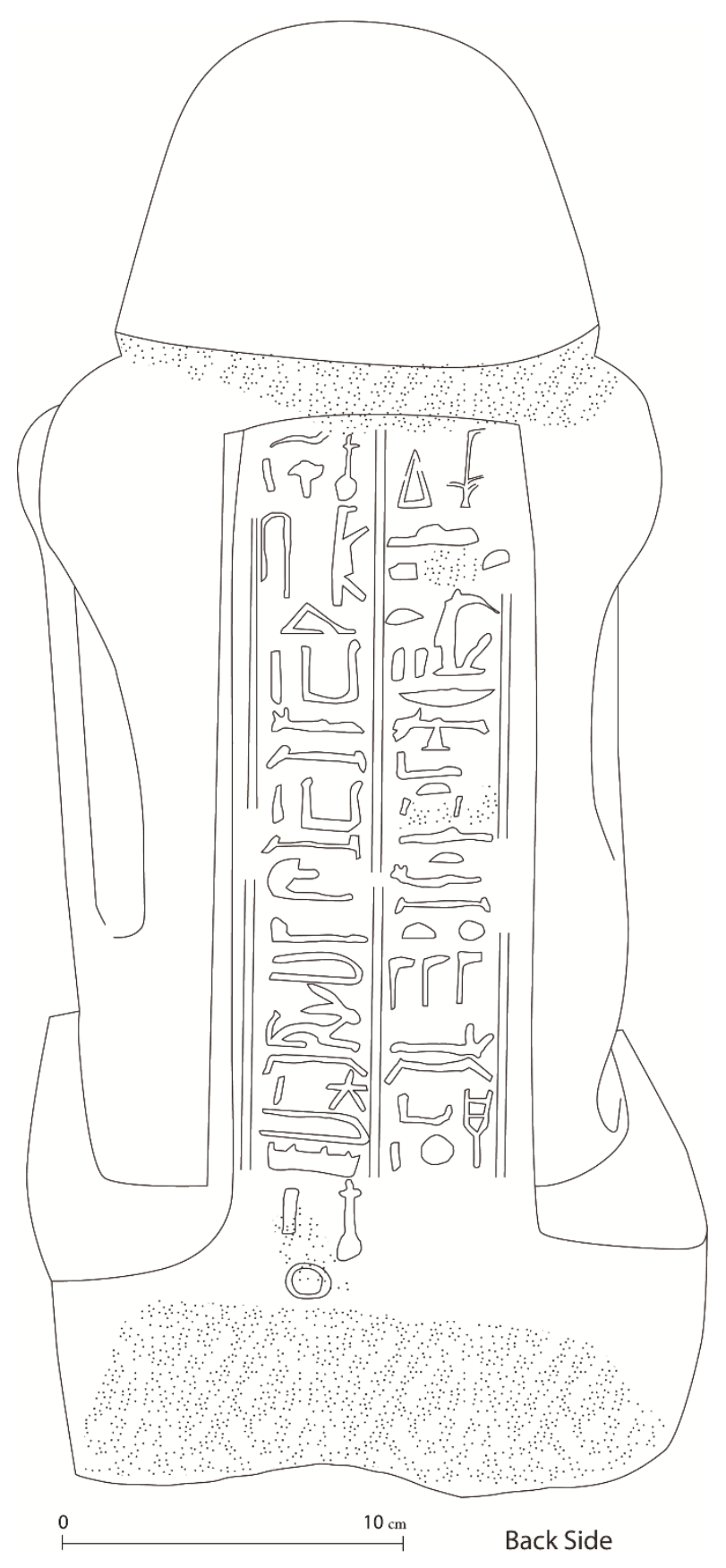

Figure (7)

Facsimile of the back of block Statue Mallawi Museum Inv. No. 326 


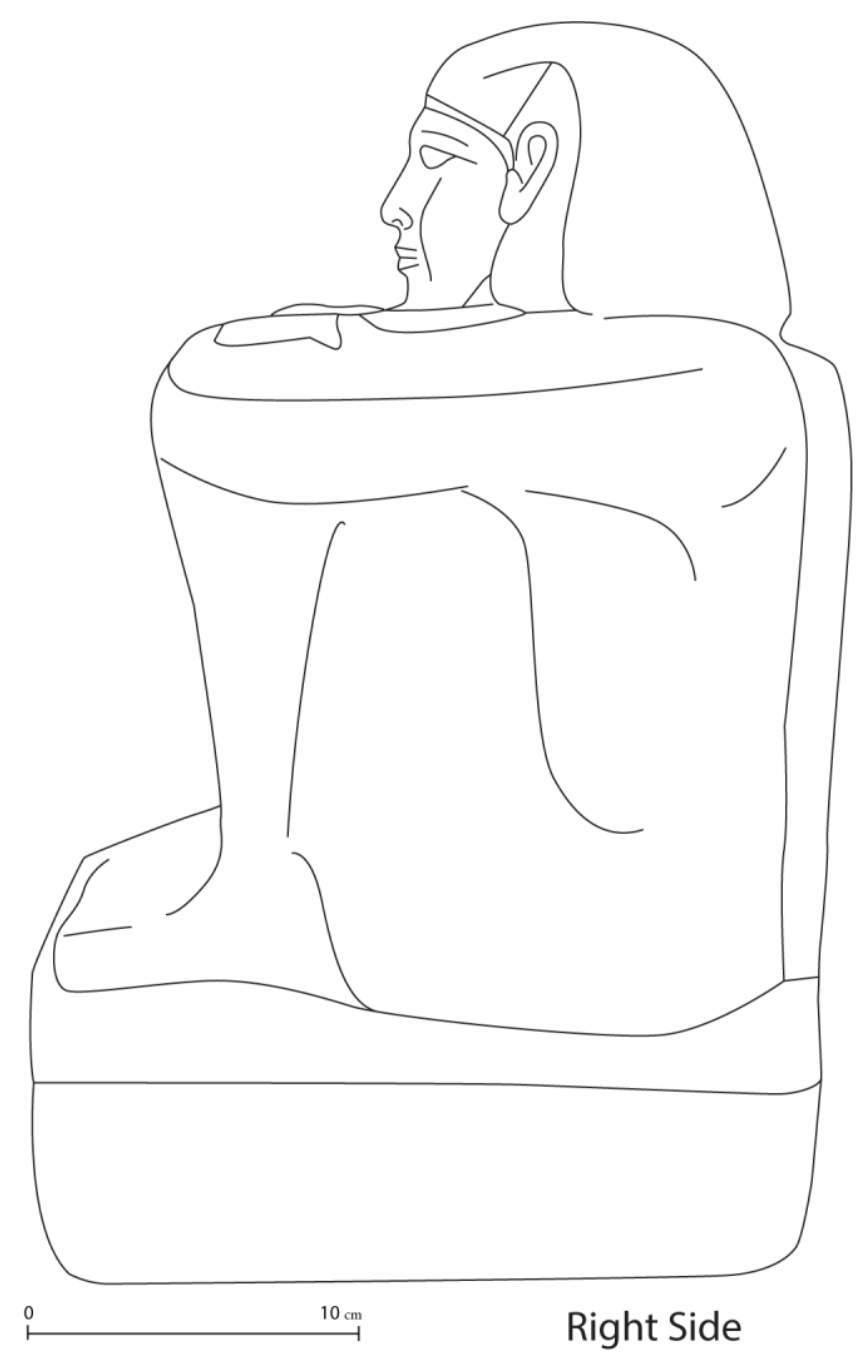

Figure (8)

Facsimile of the right side of block statue

Mallawi Museum Inv. No. 326 


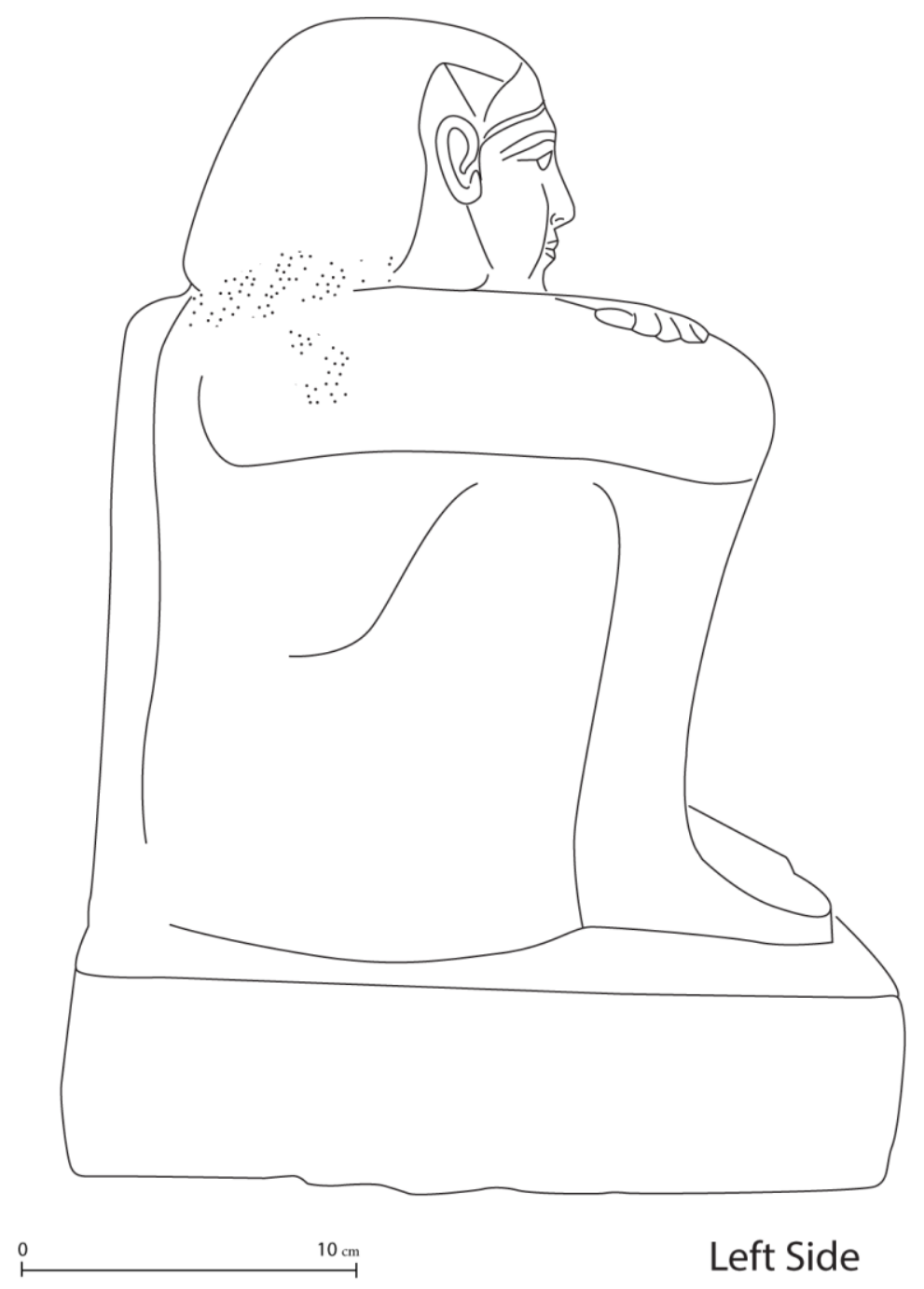

Figure (9)

Facsimile of the left side of block statue

Mallawi Museum Inv. No. 326 
تمثال كتلة غير منشور رقم צب ب في متحف ملوي

إعداد

د. ص.بر محمد صادق سالم

مدرس بقسم الآثار كلية الآداب _ جامعة دمنهور صنائ سمالم

المستخلص: تتناول هذه المقالة تمثال كتلة غير منشور موجود حاليا في متحف ملوي. يتهي يتميز هذا

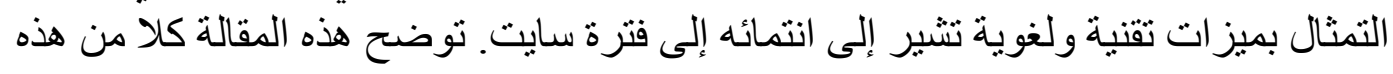

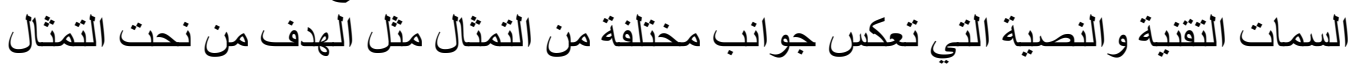

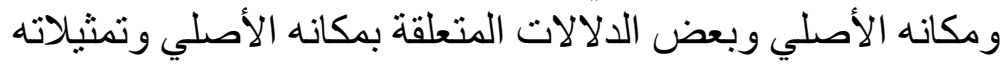

الكلمات الإفتتاحية: تمثال بلوك ، متحف ملوي ، مجلة البهنسة ، (؟) ـالفترة المتأخرة، 